\title{
Emotional burnout in professional activity of a technical university teacher
}

\author{
M.V. Kuimova ${ }^{1}$, H. Uzunboylu ${ }^{2}$, A.S.M. Chen ${ }^{3}$, E.V. Gerasimchuk ${ }^{1}$ \\ ${ }^{1}$ National Research Tomsk Polytechnic University, Tomsk, Russia \\ mkuimova@mail.ru \\ ${ }^{2}$ Near East University, Nicosia, Turkey \\ ${ }^{3}$ Center for General Education, Tatung University, Taipei, Taiwan.
}

\begin{abstract}
Higher education makes high demands on a teacher, his knowledge, pedagogical skills and personal features to ensure that he meets the demands of students and the requirements of employers. Teachers are under constant pressure to innovate, to update their knowledge in their field, and to improve students' test scores. Teacher frustration and emotional burnout may be caused by too high a workload, a lack of appreciation for their efforts, and ineffective management.

The authors studied the phenomenon and causes of emotional burnout. They researched the burnout syndrome among university teachers with over 20 years of teaching experience, by using a short questionnaire. And they provide recommendations for further studies.
\end{abstract}

Keywords: emotional burnout; higher education; job satisfaction; occupational stress; teacher burnout.

\section{Introduction}

Many studies point to the conclusion that teaching is a highly stressful career. Undoubtedly, stress negatively influences personal and career motivation, lessens job satisfaction, decreases professional and personal competence. Prolonged stress, imbalance between intellectual and energy expenses and the moral and material compensation, high cognitive complexity of interpersonal communication, emotional intensity of labor may lead to emotional burnout.

The purpose of this study is to research the burnout syndrome among university teachers whose length of teaching experience is over 20 years. The participants of the study were 27 teachers of National Research Tomsk Polytechnic University. The study employed the following methods: literature review, survey and data analysis.

\section{Related work}

Extensive literature highlights that teachers, experiencing pressures related to achieving high professional goals, great stress and reduced personal accomplishment, are more subject to burnout [Bachkirova, 2005; Steinhardt, Smith Jaggars, Faulk \& Gloria, 2011; Clipa \& Ignat 2012; Clipa \& Boghean, 2015; Colomeischi, 2015; Visotskaya, Cherkashina, Katcin \& Lisina, 2015;]. Prolonged stress, failure to meet the work challenges and adjust to the changes of teaching conditions, high job demands, depletion of personal resources lead to burnout which in its turn results in emotional exhaustion and poor health [Hakanen, Bakker \& Schaufeli, 2006]. Additionally, teacher burnout negatively affects not only his own mental and physical health but also causes conflicts between himself and his colleagues [Pishghadam, Adamson, Sadafian \& Kan, 2014].

C. Maslach and S.E. Jackson give the following definition to burnout: "It is a syndrome of emotional exhaustion, depersonalization and diminished personal accomplishment" 
[Maslach \& Jackson, 1986]. Burnout syndrome is a process of gradual loss of the expansive, cognitive and physical energy, which manifests itself in the symptoms of emotional, mental exhaustion, physical fatigue, personal detachment and reduced job satisfaction. Emotional exhaustion weakens the physical resources of the individual, decreases resistance to stress, limits the variation of the search of other sources of development, and prevents the need for self-development and self-actualization.

It is widely accepted that emotional burnout is a three-part phenomenon: weariness of emotional reserves, depersonalisation and an increasing feeling of work-related dissatisfaction [Watts \& Robertson, 2011; Madaliyeva, Mynbayeva, Sadvakassova \& Zholdassova 2015]. Researchers point out the following reasons for this syndrome:

- workaholism;

- irregular working hours;

- workload and emotional demands;

- bad job management;

- arrogant management;

- poor relations among fellow colleagues;

- poor student behavior and academic outcomes;

- constant problem-solving;

- prolonged stress;

- reduced self-esteem;

- lack of moral rewards of the work (poor classroom learning environment, frustration in the pursuit of good teaching);

- unfair evaluation system (financial and other) [Jennings, Frank, Snowberg, Coccia \& Greenberg, 2013; Näring, Vlerick \& van de Ven, 2012; Randelović, Stojiljković \& Milojević, 2013].

The following conditions may likewise lead to emotional burnout:

- inharmonious joint actions of employees;

- discontent with professional advancement and status; others;

- perfectionism and constant striving to do everything very well, preferably better than

- excessive dependence on the opinions of others, lack of autonomy and independence;

- tendency to introversion.

Uncertain, long work hours, unclearly defined responsibilities and work that doesn't receive proper evaluation also effect the development of burnout. The management style as well has a negative impact if the "boss" does not allow the employee to show independence and deprives him of a sense of responsibility for his work, or misapprehends the significance and importance of the work performed.

\section{Findings and Discussion}

It is worth noting that teacher's emotional stability is one of the most pressing challenges as his professional tasks are not only to transfer knowledge, skills and development of students' intellectual abilities, but also to foster and help form a skilled, creative personality. Teaching is a creative art that requires emotional engagement, curiosity, genuine desire to learn and a wide range of personal interests in order to develop learners' abilities to acquire new knowledge and begin to spawn original ideas. Teachers are vulnerable to work-related stress. If a teacher is clinically anxious or depressed, he may not work effectively and engage students into learning well. 
To research emotional burnout among teachers, we developed a questionnaire based on the Maslach Burnout Inventory (MBI) and polled twenty-seven teachers of foreign languages at National Research Tomsk Polytechnic University whose teaching experience is over 20 years. They could choose the following answers to the questions: never, sometimes, very often.

- I feel emotionally exhausted;

- After work, I feel like a "squeezed lemon";

- In the morning I feel fatigue and reluctance to go to work;

- After working I want to hole up for a while;

- I feel depression and apathy;

- My job disappoints me all the more;

- It seems to me that I work too much;

- I want to retire and take a break from everything and everyone; work.

- I feel indifference and loss of interest to many things that used to please me in my

The collected data reveals the presence of different degrees of burnout among teachers with the work experience of over 20 years:

Table 1. The results of the poll among twenty-seven teachers of foreign languages at National Research Tomsk Polytechnic University.

\begin{tabular}{|l|l|c|c|c|}
\hline \multirow{2}{*}{$№$} & \multicolumn{1}{|c|}{ Questions } & \multicolumn{3}{|c|}{ Answers } \\
\cline { 3 - 5 } & \multicolumn{1}{|c|}{ Never (\%) } & Sometimes (\%) & Very often (\%) \\
\hline 1 & I feel emotionally exhausted & 4 & 81 & 15 \\
\hline 2 & $\begin{array}{l}\text { After work, I feel like a } \\
\text { "squeezed lemon" }\end{array}$ & 59 & 33 & 4 \\
\hline 3 & $\begin{array}{l}\text { In the morning I feel fatigue } \\
\text { and reluctance to go to work }\end{array}$ & 89 & 7 & 85 \\
\hline 4 & $\begin{array}{l}\text { After working I want to hole } \\
\text { up for a while }\end{array}$ & 0 & 15 & 4 \\
\hline 5 & $\begin{array}{l}\text { I feel depression and apathy } \\
\text { My job disappoints me all the } \\
\text { more }\end{array}$ & 96 & 4 & 11 \\
\hline 7 & $\begin{array}{l}\text { It seems to me that I work too } \\
\text { much }\end{array}$ & 0 & 70 & 11 \\
\hline 8 & $\begin{array}{l}\text { I want to retire and take a } \\
\text { break from everything and } \\
\text { everyone }\end{array}$ & 19 & 33 & 26 \\
\hline 9 & $\begin{array}{l}\text { I feel indifference and loss of } \\
\text { interest to many things that } \\
\text { used to please me in my work }\end{array}$ & 41 & & 0 \\
\hline
\end{tabular}

In addition, we interviewed teachers to name the things that influence their occupational stress. Here there are the answers:

- excessive number of tasks that are required to be done (67\%);

- new and additional demands (56\%);

- time pressure and extra organizational pressures (44\%); 
- low salary $(41 \%)$;

- unsupportive administrators $(26 \%)$;

- apathetic students (7\%).

From there, we would recommend managers to clarify to employees their place in the organization, functions, rights and duties; develop corporate or organizational spirit and create a favorable psychological climate to cope with multiple tasks, and elaborate a system of financial incentives to help teachers avoid emotional burnout and stay emotionally-balanced, creative professionals.

In addition, to overcome fatigue and stress that make a teacher ineffective and unhappy with his work, in continuation of many researchers, we recommend taking these preventive measures:

- collaborate with administration and get its support;

- manage classroom routines;

- leave work at work and do not take it home;

- enlarge communication, do not hide feelings from yourself or from others (talk about your experiences);

- discuss problems and find strategies to solve them;

- try a more positive attitude towards life;

- take care of the attractiveness of your appearance, which reflects the state of mental health - intellectual, emotional and moral will;

- keep to a balanced diet, take care of your health and go in for sports;

- be sure to get enough sleep;

- extend your range of interests and introduce novelty into your life;

- go abroad for educational and social purposes;

- find a hobby to your liking;

- spend more time outdoors.

\section{Conclusion}

Thus, it is not a secret that education performance is unlike the way a business runs, for it depends on many undependable personal conditions that are out of teachers' control. Standard or unfair evaluation, prolonged occupational stress, emotional exhaustion, work dissatisfaction can discourage teachers' confidence and lead to poor physical health, mental wearing out, work efficiency decrease and as a result, to burnout. However, when there is a fair personnel policy, possibility for career advancement, effective leadership, access to the administration for dialogue, availability of generally accepted standards of formal and informal behavior of teachers in the institution and when a teacher has the abilities to manage his work and class, students will energize and inspire him, and all these will make teaching a more rewarding activity.

Further studies could investigate the dependence of the burnout syndrome on the age and employment period of teachers, as well as correlation of the burnout syndrome with different personality traits.

\section{References}

Bachkirova, T. (2005) Teacher stress and personal values: An exploratory study. School Psychology International, Volume 26, Issue 3, pp. 340-352.

Steinhardt, M.A., Smith Jaggars, S.E., Faulk, K.E. \& Gloria, C.T. (2011). Chronic work stress and depressive symptoms: Assessing the mediating role of teacher burnout. Stress and Health, 
Volume 27, Issue 5, pp. 420-429.

Clipa, O. \& Ignat, A.-A. (2012). Teachers satisfaction with life, job satisfaction and their emotional intelligence. Procedia Social and Behavioral Sciences, Volume 33, pp. 498-502.

Clipa, O. \& Boghean, A. (2015). Stress Factors and Solutions for the Phenomenon of Burnout of Preschool Teachers. Procedia - Social and Behavioral Sciences, Volume 180, pp. 907915.

Colomeischi, A.A. (2015). Teachers Burnout in Relation with Their Emotional Intelligence and Personality Traits. Procedia - Social and Behavioral Sciences, Volume 180, pp. 10671073.

Visotskaya, N., Cherkashina, E., Katcin, O. \& Lisina, L. (2015). Studies on University Professors' Emotional Burnout. Procedia - Social and Behavioral Sciences, Volume 214, pp. 769-778.

Hakanen, J.J., Bakker, A.B. \& Schaufeli, W.B. (2006). Burnout and work engagement among teachers. Journal of School Psychology, Volume 43, Issue 6, pp. 495-513.

Pishghadam, R., Adamson, B., Sadafian, S.S. \& Kan, F.L.F. (2014). Conceptions of assessment and teacher burnout. Assessment in Education: Principles, Policy and Practice, Volume 21, Issue 1, pp. 34-51.

Maslach, C. \& Jackson, S.E. (1986). Maslach Burnout Inventory Manual, $2^{\text {nd }}$ Edition. Palo Alto: Consulting Psychologists Press.

Watts, J. \& Robertson, N. (2011). Burnout in university teaching staff: A systematic literature review (Review). Educational Research, Volume 53, Issue 1, pp. 33-50.

Madaliyeva, Z., Mynbayeva, A., Sadvakassova, Z. \& Zholdassova, M. (2015). Correction of burnout in teachers. Procedia - Socal and Behavioral Sciences, Volume 171, pp. 1345-1352.

Jennings, P.A., Frank, J.L., Snowberg, K.E., Coccia, M.A. \& Greenberg, M.T. (2013). Improving classroom learning environments by cultivating awareness and resilience in education (CARE): Results of a randomized controlled trial. School Psychology Quarterly, Volume 28, Issue 4, pp. 374-390.

Näring, G., Vlerick, P. \& van de Ven, B. (2012). Emotion work and emotional exhaustion in teachers: the job and individual perspective. Educational Studies, Volume 38, Issue 1, pp. 6372.

Randelović, K., Stojiljković, S. \& Milojević, M. (2013). Personal factors of burnout syndrome in teachers in the framework of self-determination theory. Zbornik Instituta za Pedagoska Istrazivanja, Volume 45, Issue 2, pp. 260-281. 